\title{
Distinct different expression of Th17 and Th9 cells in coxsackie virus B3-induced mice viral myocarditis
}

Kong Qing ${ }^{1,2}$, Wu Weifeng ${ }^{1,2^{*}}$, Yang Fan ${ }^{1,2}$, Yan Yuluan ${ }^{1,2}$, Pang $Y u^{1,2}$ and Huang Yanlan ${ }^{1,2}$

\begin{abstract}
Background: Recently, a new subset of $C D 4^{+} T$ helper(Th) cell that predominantly secret cytokine interleukin-9(IL-9) is identified, termed Th9 cell. It has been reported to participate in tissue inflammation and autoimmune responses, and induce disease which differed from Th17 cells. Th17 cells have been shown to play a critical role in viral myocarditis (VMC), but whether Th9 cells are involved in the pathogenesis of VMC remains unclear.

Results: BALB/C mice were intraperitoneally (i.p) injected with coxsackie virus B3(CVB3) for establishing VMC models. Control mice were treated with phosphate-buffered saline i.p. On day $0,7,14,21,28,35,42$ after injection, myocardial histopathological changes were evaluated by hematoxylin-eosin staining. Splenic Th17 and Th9 cells subsets were analyzed by flow cytometry. And cardiac IL-17, IL-9 mRNA were measured by semi-quantitative reverse transcription-PCR and nested PCR, respectively. Results showed the levels of Th17 cells and IL-17 mRNA obviously increased in VMC mice on 7 day after infection, peaked on day 28, and highly persisted to at least day $42(p<0.05)$. While the frequencies of Th9 cells and IL-9 mRNA showed no significant difference between VMC and control group throughout the course of the experiment $(p>0.05)$.
\end{abstract}

Conclusions: It was differentiated Th17 but not Th9 cells significantly elevated in the development of CVB3induced VMC. The microenvironment of VMC seemed to contribute to the differentiation and proliferation of Th17 rather than Th9 cells. Our preliminary data implied Th9 cells could not protect against VMC nor promote the disease.

\section{Background}

Viral myocarditis(VMC) is an important cause of heart failure in young adults and often progresses to chronic myocarditis, dilated cardiomyopathy $(\mathrm{DCM})$ requiring heart transplantation[1]. CVB3, an enterovirus of Picornaviridae family, is believed to be the primary pathogen in human VMC[1,2]. Multiple studies had established that intraperitoneal inoculation of BALB/c mice with heart-passaged CVB3 (Nancy strain), can induce inflammatory heart disease which closely resembled human VMC[3], and thus this model has been widely used for investigating VMC. Previous experiments had indicated the major mechanisms in the pathogenesis of VMC were inflammation and autoimmune responses triggered by the viral infection and mediated by $\mathrm{T}$ cells $[4,5]$.

\footnotetext{
* Correspondence: wucna@yahoo.com.cn

'Guangxi Cardiovascular Institute, Shuang-Yong Road 6, Nanning, China Full list of author information is available at the end of the article
}

Besides Th1,Th2 and Treg cells, our previous report and other researches demonstrated Th17 cells which preferentially secret cytokine IL-17 might play an important role in mediating inflammation of $\mathrm{VMC}[6-9]$. But the fundamental mechanisms responsible for VMC are not completely clarified.

Recently, a novel independent Th-cell subset, "Th9" cells had been recognized[10,11]. Driven by the combined effects of TGF- $\beta$ and IL-4, it produces large quantities of IL-9 which has long been thought to be a Th2 cytokine. Beside IL-10, Th9 cells secret small amounts of other Th2-related cytokines such as IL-4, IL-5 and IL-13. Although the mechanism for the differentiation and proliferation of Th9 cells have not been fully elucidated, the specific transcription factor PU.1 and interferon-regulatory factor 4 strongly support the existence and functional relevance of Th9 cells in vivo[12,13]. Developing literature has demonstrated that Th9 cells

\section{Biomed Central}


were associated with colitis, peripheral neuritis, experimental autoimmune encephalomyelitis (EAE) and allergic disease[11-17]. Especially, a recent study indicated that IL-9 involved in antiviral immunity, regulating $\mathrm{T}$ and $B$ cell responses to respiratory syncytial virus infection in BALB/c mice[18]. It seems Th9 cells provide a unique contribution to tissue inflammation and immune responses, and participate in Th17-mediated diseases. Additionally, Anneli Jäger and colleagues reported Th17 and Th9 effector cells induced EAE, an animal model of human multiple sclerosis, with different pathological phenotypes, indicated distinct effector function of Th17 and Th9 cells[14]. Th17 cells had been shown to be associated to inflammation of CVB3-induced mice VMC, whether the unique IL-9 producing cells, Th9 participate in development of VMC and whether the expression level of Th17 differ from Th9 cells remain to be determined. In this study, we compared the Th9 and Th17 functions on different level including cell frequencies and major cytokine secretion to preliminarily explore whether Th9 cells involved in the pathogenesis of CVB3-induced mice VMC, and whether Th9 and Th17 cells differentially expressed in VMC.

\section{Methods \\ Animals}

Specific pathogen-free male BALB/c mice(6 weeks of age) were obtained from Shanghai Laboratory Animal Center, Chinese Academy of Sciences, Shanghai, China (Certificate No.0062353 -SCXK (SH) 2007-0005). All animals were housed under pathogen-free conditions at the Experimental Animal Center of the Guangxi Medical University. All experiments using mice were performed in accordance with protocols approved by Guangxi Medical University Animal Ethics Committee.

\section{Interventions and groups}

Heart-passaged CVB3 (Nancy strain, from Institute of immunology of Guangxi Medical University) was maintained by passage through Hep- 2 cells. $50 \%$ tissue culture infectious dose (TCID50) assay of Hep-2 cell was 1 $\times 10^{-7}$. The CVB3 was diluted in PBS (Solarbio Science \& Technology Co, Ltd, Beijing, China). A total of 105 mice were randomly divided into $\mathrm{VMC}(\mathrm{n}=70,10 \mathrm{mice} /$ subgroup) and control groups ( $\mathrm{n}=35,5 \mathrm{mice} /$ subgroup). Each group was divided into 7 subgroups (Day0, Day7, Day14,Day21,Day28,Day35,Day42). The VMC group was treated with (i.p.) $0.1 \mathrm{ml}$ PBS containing approximately 100TCID50 of the virus. Mice injected (i.p.) with $0.1 \mathrm{ml}$ PBS were taken as control. The day of injection was defined as day 0 . Surviving mice of 7 subgroups were separately sacrificed by cervical dislocation on 7 different time points, which were day $0,7,14,21,28,35,42$ after injection. Hearts and spleens were removed aseptically as fresh specimens to be measured.

\section{Histopathological examination}

The hearts were fixed in 10\% formalin, then embedded in paraffin. After sectioned along the entire length of the heart into $5-\mu \mathrm{m}$ sections, and stained with $\mathrm{H} \& \mathrm{E}$ (hematoxylin and eosin), histopathological change was observed by using light microscopy(Nikon Eclipse E800 Microscope, Kawasaki, Kanagawa, Japan). Pathological scores were graded by two independent researchers in a blinded manner according to the following scoring system: 0 , no inflammatory infiltrates; 1 , small foci of inflammatory cells between myocytes or inflammatory cells surrounding individual myocytes; 2, larger foci of 100 inflammatory cells or involving at least 30 myocytes; $3,10 \%$ of a myocardial cross-section involved; $4,30 \%$ of a myocardial cross-section involved[19].

\section{Flow cytometric analysis of Th17 and Th9 cells}

Splenic cells were gently dispersed through nylon mesh into a single-cell suspension, washed with RPMI 1640 (Gibco, USA). Lymphocytes were obtained by density gradient centrifugation from cells with Ficoll Paque (Solarbio Science \&Technology). These cells were suspended in RPMI 1640 medium with 10\% FCS (Gibco, USA) and transferred to each well of 24-well plates. Cultures were stimulated with phorbol myristate acetate (PMA, $25 \mathrm{ng} / \mathrm{ml}$, Sigma-Aldrich, USA) and ionomycin $(1 \mu \mathrm{g} / \mathrm{ml}$, Sigma-Aldrich) in the presence of GolgiPlug $\left(10^{6} 1 \mathrm{ul} /\right.$ cells, BD Biosciences) at $37^{\circ} \mathrm{C}$ under a $5 \% \mathrm{CO}_{2}$ environment. After $4 \mathrm{~h}$ of incubation, cells were harvested and washed once with PBS. Then cells were incubated with phycoerythrin Cye-5-conjugated anti-mouse CD4 (PE-Cye-CD4, BD Biosciences). After washed with PBS, cells were fixed in $4 \%$ paraformaldehyde, permeabilized with $0.1 \%$ saponin. Then cells were stained with phycoerythrin-conjugated anti-mouse IL-17 and Alexa Fluor $^{\circledR} 647$ anti-mouse IL-9, and analyzed on a FACSCalibur flow cytometer (BD Bioscience). CellQuest software (BD Biosciences) was used for data acquisition.

\section{Polymerase chain reaction(PCR) of IL-17 and IL-9 mRNA}

Total RNA of heart tissues was extracted using TRIZOL Reagent ${ }^{\mathbb{B}}$ (Invitrogen, USA), and then converted into cDNA using an Reverse Transcription kit (Ferma, USA) according to the manufacturer's protocol. The primers for IL-17A, IL-9 and the housekeeping gene $\beta$-actin were designed by Primer Premier 5.0 (Table 1). For IL17A amplification semi-quantitative reverse transcription-PCR was performed under the following conditions: pre-heating at $94^{\circ} \mathrm{C}$ for $3 \mathrm{~min}$, denaturing at $94^{\circ} \mathrm{C}$ for 30 second(s), annealing at $64.9^{\circ} \mathrm{C}$ for $30 \mathrm{~s}$, and extension at $72^{\circ} \mathrm{C}$ for $60 \mathrm{~s}$. The reaction repeated for 35 cycles 
Table 1 Sequences of primers for PCR

\begin{tabular}{|c|c|c|}
\hline Molecule & Sequence $\left(5^{\prime}-3^{\prime}\right)$ & Length \\
\hline IL-17 & sense:5'GTCAATGCGGAGGGAAAG 3' & $349 \mathrm{bp}$ \\
\hline [GenBank:16171] & antisense:5'CACGAAGCAGTTGGGAC 3' & \\
\hline$\beta$-actin & sense: 5'CCAGCCTTCCTTCTTGGGTAT 3' & 102 bp \\
\hline [GenBank:11461] & antisense: 5'TTGGCATAGAGGTCTTACGG 3' & \\
\hline IL-9 & $\begin{array}{l}\text { PCR1 sense: 5'GCATCAGAGACACCAATTACCT } \\
3^{\prime}\end{array}$ & $140 \mathrm{bp}$ \\
\hline \multirow[t]{3}{*}{ [GenBank:16198] } & $\begin{array}{l}\text { PCR1 antisense: } 5^{\prime} \\
\text { TTAAGGAGGGGAGTITGTA 3' }\end{array}$ & \\
\hline & $\begin{array}{l}\text { PCR2 sense: } \\
\text { 5'AACTGATGATTGTACCACACCGTGC 3' }\end{array}$ & \\
\hline & $\begin{array}{l}\text { PCR2 antisense: 5' } \\
\text { AGGACGGACACGTGATGTTCTTAG 3' }\end{array}$ & \\
\hline
\end{tabular}

followed by incubation at $72^{\circ} \mathrm{C}$ for $10 \mathrm{~min}$. Products were separated using $2 \%$ agarose gel electrophoresis and visualized by $0.5 \mathrm{mg} / \mathrm{ml}$ ethidium bromide staining and ultraviolet transillumination. The resulting bands (349 bp) were measured using the Digital Gel Imaging Analyst (Nikon 990-Doc 1000, USA). Background density was subtracted from each band and the relative IL-17 mRNA expressions were normalized to the level of $\beta$ actin transcripts. For IL-9, reverse transcription-PCR shown its mRNA was undetectable in heart. Then we amplified with nested PCR which contains the first and second round PCR reaction(PCR1 and PCR2). Specific primers were used for PCR1 reaction. After $3 \mathrm{~min}$ at $72^{\circ}$ C, 40 amplification cycles were used $\left(94^{\circ} \mathrm{C}\right.$ for $45 \mathrm{~s}, 56^{\circ} \mathrm{C}$ for $45 \mathrm{~s}$, and $72^{\circ} \mathrm{C}$ for $1 \mathrm{~min}$ ), then $72^{\circ} \mathrm{C}$ for $6 \mathrm{~min}$. PCR 1 products and specific primers were used for PCR2. The polymerase was activated by incubation at $95^{\circ} \mathrm{C}$ for $3 \mathrm{~min}$ prior to 40 amplification cycles $\left(94^{\circ} \mathrm{C}\right.$ for $30 \mathrm{~s}, 58^{\circ} \mathrm{C}$ for $30 \mathrm{~s}$, and $72^{\circ} \mathrm{C}$ for $30 \mathrm{~s}$ ), followed by $3 \mathrm{~min}$ at $72^{\circ} \mathrm{C}$. After PCR2 products were separated by electrophoresis, the purpose gene were investigated in all samples. IL-9 frequency was determined via direct counting. The presence of $140 \mathrm{bp}$ band indicated the expression of IL-9mRNA, while its absence confirmed no expression. Sterile water was also amplified with nested PCR as the negative controls. Products were sequenced by Sangon Biological Engineering Technology \& Services Co., Ltd., (Shanghai, China), and blasted in the NCBI Blast bank. All samples were measured in triplicate.

\section{Statistical analysis}

Quantitative variables were expressed as mean \pm standard deviation (SD). One-way ANOVA was used for comparison among groups. Qualitative variables of IL-9 mRNA measured by nested-PCR were expressed as percentages, and differences in IL-9 mRNA distribution among groups were obtained using the Chi-Square Tests. Statistical analyses were performed with the use of SPSS 13.0, $\mathrm{p}<0.05$ was considered statistically significant.

\section{Results}

Development of VMC

Signs of VMC were apparent in the experimental group after virus injection, including weakness, coat ruffling, irritability, back arching, lethargy, anorexia, weight loss, and some mice died. Number of surviving mice in VMC subgroups from day 0 to 42 were: 10, 9, 7, 6, 6, 7 and 7, respectively. The cardiac pathological scores of VMC significantly increased on day $7(1.8 \pm 0.5)$, peaked on day $14(2.8 \pm 0.4)$. Then the severity of inflammation gradually ameliorated. In contrast, the control group showed no inflammatory cell infiltration, necrosis or fibrosis lesions in hearts, and no mice died(Figure 1).

\section{Distinct frequencies of Th17 and Th9 cells}

As shown in Figure 2, frequencies of splenic Th17 cells $\left(\mathrm{CD} 4^{+} \mathrm{IL}_{17}{ }^{+} / \mathrm{CD}^{+} \mathrm{T}\right.$ cells) in VMC group from day 0 to 42 were: $0.76 \pm 0.34 \%, 2.32 \pm 0.78 \%, 2.70 \pm 0.86 \%, 2.72$ $\pm 0.72 \%, 4.99 \pm 0.85 \%, 2.94 \pm 0.48 \%, 2.24 \pm 0.42 \%$. Th17 cells in the control group from day 0 to 42 were $0.87 \pm$ $0.45 \%, 0.93 \pm 0.14 \%, 0.82 \pm 0.09 \%, 0.97 \pm 0.43 \%, 0.98 \pm$ $0.42 \%, 0.96 \pm 0.54 \%, 1.02 \pm 0.63 \%$. These data indicated the time-course of Th17 cells were significant higher than control group from day 7 , and peaked on day 28 , then wanning $(\mathrm{p}<0.05)$. Frequencies of Th9 cells (CD4 ${ }^{+} \mathrm{IL}^{+} / \mathrm{CD}^{+}{ }^{+} \mathrm{T}$ cells) in VMC group from day 0 to 42 were: $0.62 \pm 0.17 \%, 0.58 \pm 0.21 \%, 0.61 \pm 0.24 \%, 0.67 \pm$ $0.28 \%, 0.65 \pm 0.25 \%, 0.57 \pm 0.28 \%, 0.64 \pm 0.26 \%$. Th9 cells in the control group from day 0 to 42 were $0.53 \pm$ $0.17 \%, 0.57 \pm 0.23 \%, 0.54 \pm 0.27 \%, 0.58 \pm 0.16 \%, 0.66 \pm$ $0.30 \%, 0.69 \pm 0.32 \%, 0.63 \pm 0.27 \%$. Results showed no significant difference between the VMC and control group on each time point(all $\mathrm{p}>0.05)$.

\section{Different level of IL-17 and IL-9 mRNA}

As shown in Figure 3, for cardiac IL-17 mRNA, its intensity normalized to $\beta$-actin in VMC group from day 0 to 42 were: $0.27 \pm 0.18,0.73 \pm 0.32,0.87 \pm 0.25,0.89$ $\pm 0.34,1.16 \pm 0.24,0.93 \pm 0.28,0.85 \pm 0.27$. Data in the control group from day 0 to 42 were: $0.32 \pm 0.11,0.27$ $\pm 0.15,0.32 \pm 0.18,0.35 \pm 0.13,0.36 \pm 0.17,0.29 \pm 0.14$, $0.31 \pm 0.18$. In accordance with flow cytometry analysis of Th17 cells, IL-17 mRNA obviously upregulated in mice with VMC from day 7 and peaked on day 28 (p < $0.05)$. For IL-9, the percentages of its cardiac mRNA in VMC group from day 0 to 42 were: $60 \%, 55.6 \%, 71.4 \%$, $66.7 \%, 66.7 \%, 71.4 \%, 57.1 \%$. Results in the control group were $60 \%, 40 \%, 60 \%, 60 \%, 60 \%, 60 \%$ and $40 \%$. Fisher's Exact Test was used to analyze the differences of IL-9 mRNA percentages between the VMC and control groups because of small size. No significant difference was observed throughout the course of the experiment (all p > 0.05), which was in agreement with our observations on the frequencies of Th9 cells. 


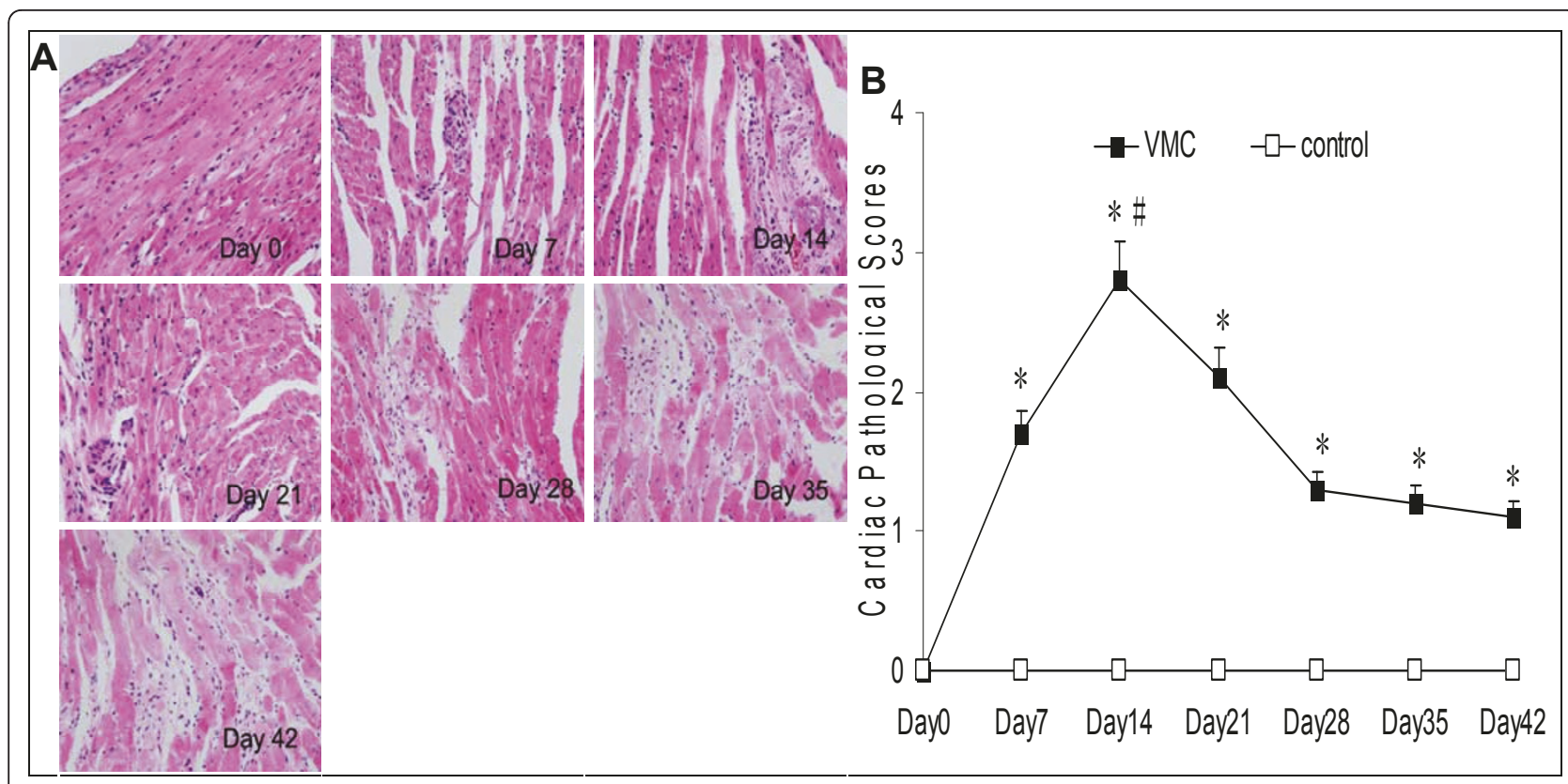

Figure 1 The severity of VMC were evaluated by histopathological examination. A. Representative of myocardial histopathologic images in VMC group (H\&E, original magnification $\times 400$ ). Myocardial was normal on Day 0 . A few scattered small foci of myocyte necrosis were observed on Day 7. The severity of myocardial necrosis and interstitial inflammatory cell infiltration were markedly increased on Day 14. Then the degree of inflammation gradually decreased. Fibrous hyperplasia was found from Day $28 \mathrm{on}$. B. The results of statistical analysis for pathological scores in different groups. $n=5$ mice for per control subgroup, $n=6-10$ for per VMC subgroup. Values are expressed as mean \pm SD. ${ }^{*}, p<0.01$ vs. control subgroups sacrificed on the same time point; $\#, p<0.05$ vs. other VMC subgroups. VMC, Viral myocarditis.

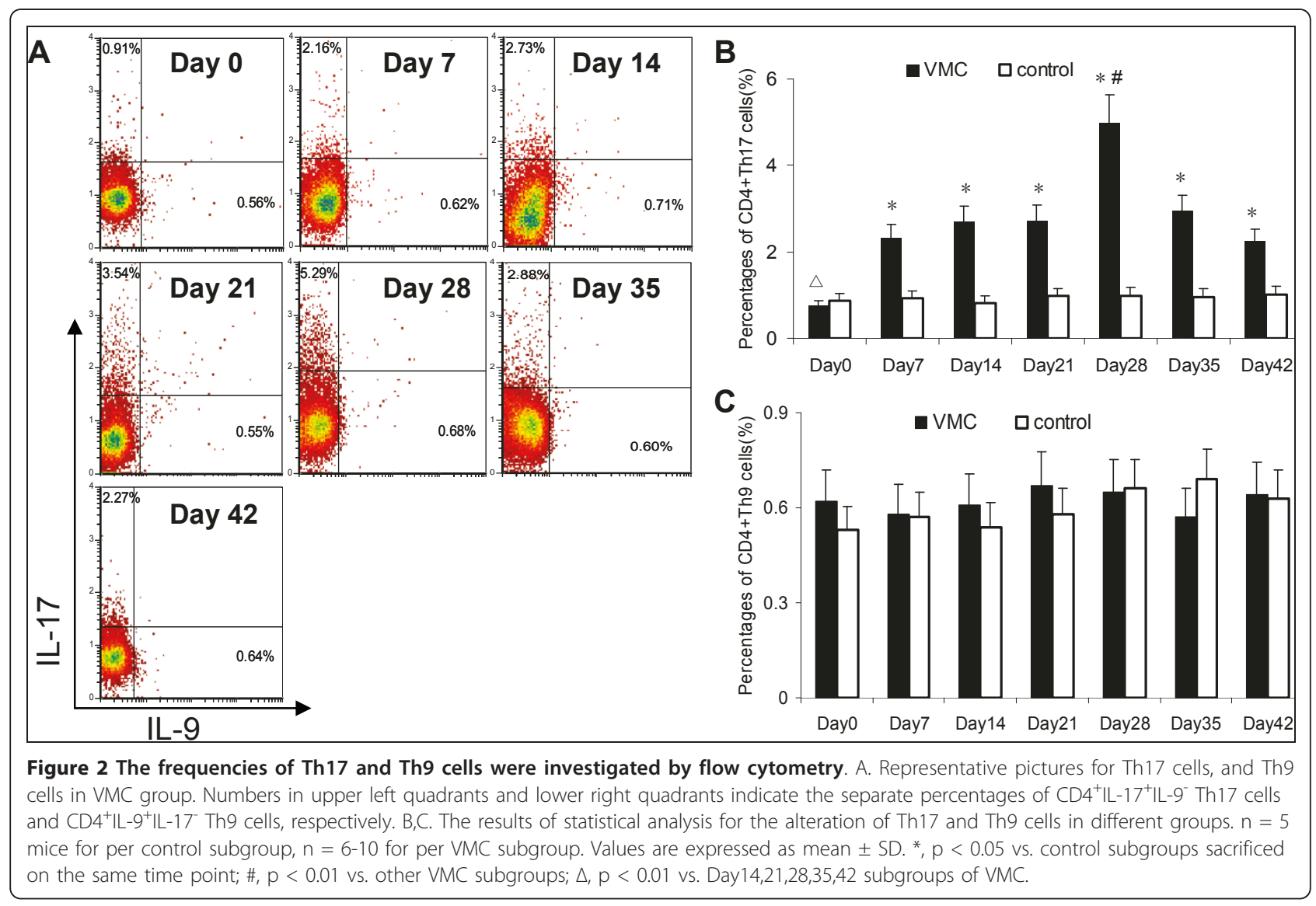




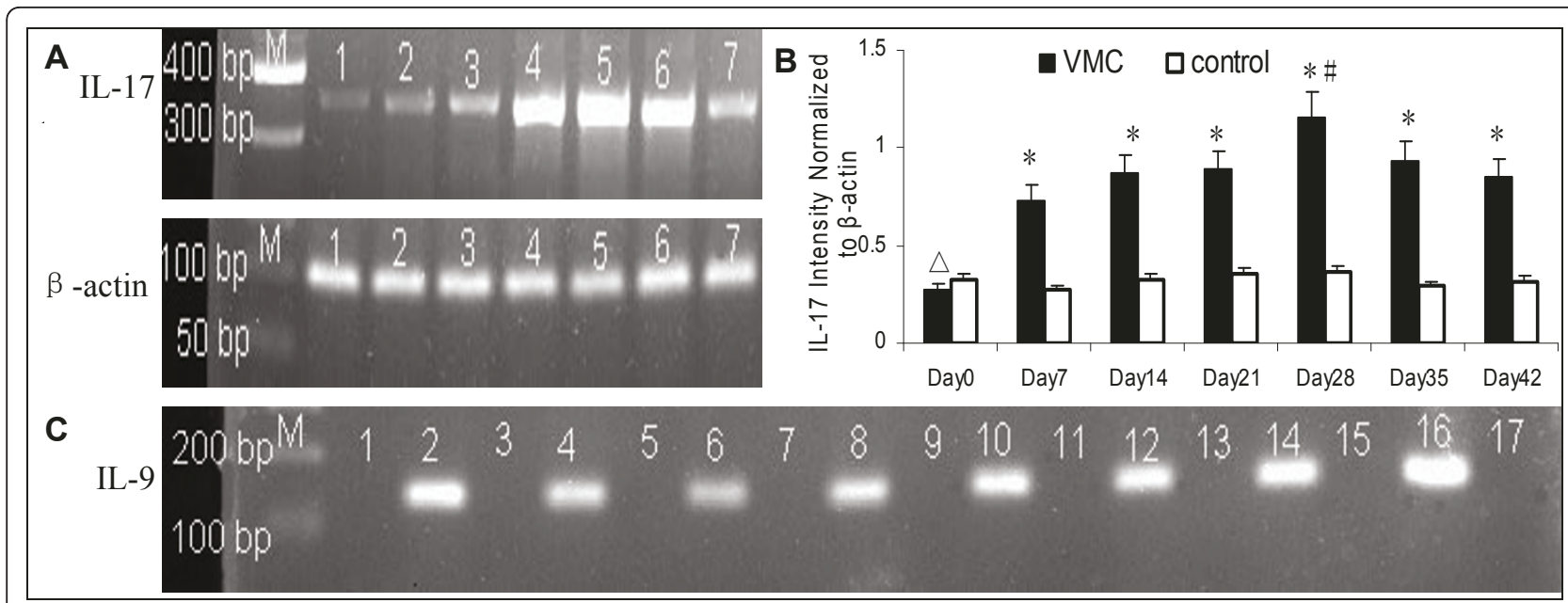

Figure 3 The levels of cardiac IL-17 and IL-9 mRNA were detected by PCR. A. Representative images showing semi-quantitative reverse transcription-PCR products for IL-17 mRNA transcription in VMC group. Lane M, 50-bp marker ladder;Lanes1-7, Day 0,7,14,21,28,35,42 subgroups. B.Collective analyses of results from all groups for IL-17 mRNA. The products were normalized versus $\beta$-actin mRNA band intensities. C. The percentages of cardiac IL-9 mRNA were detected by nested-PCR. Representative images showing PCR products of the samples. Lane M,100-bp marker ladder; Lanes 1,2, samples of control group; Lanes 3-16, samples of different time point in VMC groups; Lanes 3,4, Day0; Lanes 5,6, Day7; Lanes 7,8, Day14; Lanes9,10, Day21; Lanes11,12, Day28; Lanes13,14, Day35; Lanes 15,16, Day42. Lane17, sterile water were amplified as the negative control. $n=5$ mice for per control subgroup, $n=6-10$ for per VMC subgroup. Values are expressed as mean $\pm S D$. ${ }^{*}, p<0.01$ vs. control subgroups sacrificed on the same point time; \#, $p<0.05$ vs. other VMC subgroups; $\Delta, p<0.01$ vs. Day 14,21,28,35,42 subgroups of the VMC group.

\section{Discussion}

The results of our experiment showed that the extent of myocardial inflammatory infiltrations peaked around day 14 after injection with CVB3. It was differentiated Th17 cell and its major cytokine IL-17 dramatically increased in VMC from day 7 post-infection, and persisted at least to day 42. But for Th9 cells frequencies, there was no obvious difference between VMC and control group throughout the course of the experiment. The similar phenomena also appeared on the level of IL-9 mRNA. In agreement with low frequencies of Th9 cells in spleens, we found cardiac IL-9 mRNA was undetectable by semi-quantitative reverse transcription PCR. Then we performed a more sensitive method for original specimens, nested PCR[20]. These manifestations suggested the Th9 cells in CVB3 and PBS treated BALB/c mice might be very low.

Several recent discoveries of Th9 cells found in mice and human have broadened our understanding of autoimmune disease, because this unique IL-9-producing subset seems can explain some phenomena underlying $\mathrm{T}$ cell-mediated tissue inflammation and antiviral immunities[21]. Th9 cells might contribute to immunity against EAE, colitis and peripheral neuritis, allergic inflammation, allergic rhinitis and Alzheimer's disease[11-17,22-24]. On the other hand, emerging literature identified IL-9 involved in antiinflammatory, antiviral, nephroprotective activity, and enhanced the immunosuppressive function of Tregs $[18,25,26]$. These conflicting observations suggested Th9 cells can exert pro-inflammatory or anti-inflammatory activities, and might function as both a positive and negative regulator of immune response depending on the context. It is therefore possible that Th9 cells can protect against VMC or promote the disease, and may be differentially affected in mice with VMC or not, hence the present study was undertaken. Contrary to our hypothesis, our evidence clearly showed no significant difference of Th9 cells and IL-9 mRNA throughout the development of the VMC. Data in cell frequencies and major related cytokine secretion levels failed to demonstrate Th9 cells could be differentially regulated in mice with VMC or not. There are at least two possible explanations for our observation. Firstly, as we known, IL-9 promoted the survival and activation of various cellular targets, including mast cells, B cells, T cells, and structural cells[27,28]. IL $-9^{+} \mathrm{CD} 4^{+}$cells were detected in all groups. So we hypothesis that Th9 cells might relate to both maintenance of cardic health and heart tissue destruction by CVB3. Secondly, although there are multiple cell types responsive to IL-9, and the biological effects of IL-9 are pleiotropic[29]. Many scholars believed that IL-9 was not obligatory for pathogenesis of some diseases and other cytokines can compensate its effect. For example, IL-9 had been shown to participate in the defense against helminth infections, asthma and allergy $[17,30]$. But some experiments demonstrated that IL-9 was not required for the expulsion of the intestinal parasitic nematode Nippostrongylus brasiliensis, the chronic allergen challenge induced bronchial mast cell 
accumulation, the development of allergen-induced pulmonary inflammation or airway hyperreactivity[31-33]. In our current experiment, no change of Th9 cells had been observed in VMC. From this point of view, we can't exclude the possibility that the pathogenic process of VMC is not associated with Th9 cells. Further investigation will be of particular interest to determine whether neutralize Th9 cytokines and/or in IL-9 mutant mice especially in IL-9/IL-9R-deficient mice model, lead to different viral immunity in the CBV3-induced VMC.

Th17 cells have been identified as a unique $\mathrm{CD} 4^{+} \mathrm{Th}$ subset, which is characterized by production of proinflammatary cytokine IL-17[34]. Th17 subset has sparked great interest in the role of a broad range of immune-mediated tissue injury, including organ-specific autoimmunity in heart, VMC. Existing knowledge related to Th17 cells in VMC suggest that Th17 cells contribute to viral replication, facilitate the humoral immune response in acute VMC, and anti-IL-17 antibody can markedly reduce mice VMC severity[6-9]. Our experiment found Th17 cells highly expressed in the pathogenesis of VMC, which enriched from day 7 , peaked on day 28, persisted at least to day 42 post-infection. But the change of Th9 cells did not reach statistical significance. It seems the microenvironments of VMC contribute to differentiation and proliferation of Th17 rather than Th9 cells. Meanwhile, although investigations in vitro had presented a complex regulatory network between Th17 and Th9 cells, and IL-9 could function as an autocrine growth factor that facilitates the expansion of Th17 cells populations[14,16,25,35,36]. It seems high expression of Th17 have no effect on Th9 cells in VMC. The exact relationship between Th17 and Th9 cells need future in vitro experiment to clarify.

There are several limitations in our study. Firstly, although the Th9 is the major $\mathrm{CD} 4^{+} \mathrm{T}$ cell subset exciting IL-9, and we separately detected the $\mathrm{CD} 4^{+} \mathrm{IL}-7^{+} \mathrm{IL}-9^{-}$ $\mathrm{T}$ and $\mathrm{CD} 4^{+} \mathrm{IL}-9^{+} \mathrm{IL}-7^{-} \mathrm{T}$ cells by flow cytometry, the present study cannot ascertain whether Th17 cells produced IL-9 in VMC[12,37]. Secondly, we focused on Th9 cells'major cytokine IL-9, but we did not extensively detect other cytokine such as IL-10, which is undetectable in human. Furthermore, we did not perform study in vitro and isolate Th17/Th9 cells to explore their relationship.

\section{Conclusion}

Our preliminary data disclosed Th17 rather than Th9 cells significantly elevated in the development of CBV3 induced VMC mice, including cell frequencies and major related cytokine secretion levels. It seems the microenvironments of mice with VMC affect the differentiation and proliferation of Th17 but not Th9 cells. Whether Th9 cells participate in the pathogenesis of
VMC warrants further research. The study of these manifestations might lead to new insight into the imbalance of Th17/Th9 cells in tissue inflammation and autoimmune responses, and the Th9 cells hypothesis might evolve into an even more intricate story.

\section{Acknowledgements}

This work is supported by the grants from the National Natural Science Foundation of China (No. 30960129). We thank Dr. Lan Jiao, Liang Zoujiu, Huang Qiguang for technical assistances.

\section{Author details}

'Guangxi Cardiovascular Institute, Shuang-Yong Road 6, Nanning, China. ${ }^{2}$ Department of Cardiology, the First Affiliated Hospital of Guangxi Medical University, Shuang-Yong Road 6, 530021 Nanning, China.

\section{Authors' contributions}

KQ coordinated the study, carried out data collection, performed the statistical analysis and interpretation of data, drafted the manuscript and reviewed it. WW participated in the conception and design, coordinated the study and reviewed it. YF, YY, PY and HY carried out data collection. All authors read and approved the final manuscript.

\section{Competing interests}

The authors declare that they have no competing interests.

Received: 27 January 2011 Accepted: 2 June 2011

Published: 2 June 2011

\section{References}

1. Cooper TLeslie: Myocarditis: From Bench to Bedside. Totowa, New Jersey: Humana Press 2003.

2. Yusuf S, Reddy S, Ounpuu S, Anand S: Global burden of cardiovascular diseases: part I: general considerations, the epidemiologic transition, risk factors, and impact of urbanization. Circulation 2001, 104:2746-2753.

3. Fairweather D, Rose NR: Coxsackievirus-induced myocarditis in mice: a model of autoimmune disease for studying immunotoxicity. Methods 2007, 41:118-122.

4. Valaperti A, Marty RR, Kania G, Germano D, Mauermann N, Dirnhofer S, Leimenstoll B, Blyszczuk P, Dong C, Mueller C, Hunziker L, Eriksson U: $\mathrm{CD} 1 \mathrm{~b}+$ monocytes abrogate Th17 CD4+ T cell-mediated experimental autoimmune myocarditis. J Immunol 2008, 180:2686-2695.

5. Fairweather D, Kaya Z, Shellam GR, Lawson CM, Rose NR: From infection to autoimmunity. J Autoimmun 2001, 16:175-186.

6. Fan Y, Weifeng W, Yuluan Y, Qing K, Yu P, Yanlan H: Treatment With a Neutralizing Anti-Murine Interleukin-17 Antibody After the Onset of Coxsackievirus B3-Induced Viral Myocarditis Reduces Myocardium Inflammation. Virol I 2011, 8:17.

7. Yuan J, Yu M, Lin QW, Cao AL, Yu X, Dong JH, Wang JP, Zhang JH, Wang M, Guo HP, Cheng X, Liao YH: Th17 cells contribute to viral replication in coxsackievirus B3-induced acute viral myocarditis. $J$ Immunol 2010, 185:4004-4010.

8. Yuan J, Yu M, Lin QW, Cao AL, Yu X, Dong JH, Wang JP, Zhang JH, Wang M, Guo HP, Liao YH: Neutralization of IL-17 inhibits the production of anti-ANT autoantibodies in CVB3-induced acute viral myocarditis. Int Immunopharmacol 2010, 10:272-276.

9. Yuan J, Cao AL, Yu M, Lin QW, Yu X, Zhang JH, Wang M, Guo HP, Liao YH: Th17 Cells Facilitate the Humoral Immune Response in Patients with Acute Viral Myocarditis. J Clin Immunol 2010, 30:226-234.

10. Veldhoen M, Uyttenhove C, van Snick J, Helmby H, Westendorf A, Buer J, Martin B, Wilhelm C, Stockinger B: Transforming growth factor-beta 'reprograms' the differentiation of $T$ helper 2 cells and promotes an interleukin 9-producing subset. Nat Immunol 2008, 9:1341-1346.

11. Dardalhon V, Awasthi A, Kwon H, Galileos G, Gao W, Sobel RA, Mitsdoerffer M, Strom TB, Elyaman W, Ho IC, Khoury S, Oukka M, Kuchroo VK: IL-4 inhibits TGF-beta-induced Foxp3+ T cells and, together with TGF-beta, generates IL-9+ IL-10+ Foxp3(-) effector T cells. Nat Immunol 2008, 9:1347-1355. 
12. Chang HC, Sehra S, Goswami R, Yao W, Yu Q, Stritesky GL, Jabeen R, McKinley C, Ahyi AN, Han L, Nguyen ET, Robertson MJ, Perumal NB, Tepper RS, Nutt SL, Kaplan MH: The transcription factor PU.1 is required for the development of IL-9-producing T cells and allergic inflammation. Nat Immunol 2010, 11:527-534.

13. Staudt V, Bothur E, Klein M, Lingnau K, Reuter S, Grebe N, Gerlitzki B, Hoffmann M, Ulges A, Taube C, Dehzad N, Becker M, Stassen M, Steinborn A, Lohoff M, Schild H, Schmitt E, Bopp T: Interferon-regulatory factor 4 isessential for the developmental program of $\mathrm{T}$ helper 9 cells. Immunity 2010, 33:192-202.

14. Jäger A, Dardalhon V, Sobel RA, Bettelli E, Kuchroo VK: Th1, Th17, and Th9 effector cells induce experimental autoimmune encephalomyelitis with different pathological phenotypes. J Immunol 2009, 183:7169-7177.

15. Nowak EC, Weaver CT, Turner H, Begum-Haque S, Becher B, Schreiner B, Coyle AJ, Kasper LH, Noelle RJ: IL-9 as a mediator of Th17-driven inflammatory disease. J Exp Med 2009, 206:1653-1660.

16. Li H, Nourbakhsh B, Ciric B, Zhang GX, Rostami A: Neutralization of IL-9 ameliorates experimental autoimmune encephalomyelitis by decreasing the effector T cell population. J Immunol 2010, 185:4095-4100.

17. Soroosh P, Doherty TA: Th9 and allergic disease. Immunology 2009, 127:450-458

18. Dodd JS, Lum E, Goulding J, Muir R, Van Snick J, Openshaw PJ: IL-9 regulates pathology during primary and memory responses to respiratory syncytial virus infection. J Immunol 2009, 183:7006-7013.

19. Eriksson U, Ricci R, Hunziker L, Kurrer MO, Oudit GY, Watts TH, Sonderegger I, Bachmaier K, Kopf M, Penninger JM: Dendritic cell-induced autoimmune heart failure requires cooperation between adaptive and innate immunity. Nat Med 2003, 9:1484-1490.

20. Nix WA, Maher K, Pallansch MA, Oberste MS: Parechovirus typing in clinical specimens by nested or semi-nested PCR coupled with sequencing. J Clin Virol 2010, 48:202-207.

21. Beriou G, Bradshaw EM, Lozano E, Costantino CM, Hastings WD, Orban T, Elyaman W, Khoury SJ, Kuchroo VK, Baecher-Allan C, Hafler DA: TGF-beta induces IL-9 production from human Th17 cells. J Immunol 2010, 185:46-54

22. Kearley J, Erjefalt JS, Andersson C, Benjamin E, Jones CP, Robichaud A Pegorier S, Brewah Y, Burwell TJ, Bjermer L, Kiener PA, Kolbeck R, Lloyd CM, Coyle AJ, Humbles AA: IL-9 Governs Allergen-induced Mast Cell Numbers in the Lung and Chronic Remodeling of the Airways. Am J Respir Crit Care Med 2011, 183:865-875.

23. Ciprandi G, De Amici M, Castellazzi AM, Tosca MA, Marseglia G: Serum IL-9 Levels Depend on Allergen Exposure: Preliminary Study. Int Arch Allergy Immunol 2010, 154:246-248.

24. Saresella M, Calabrese E, Marventano I, Piancone F, Gatti A, Alberoni M, Nemni R, Clerici M: Increased activity of Th-17 and Th-9 lymphocytes and a skewing of the post-thymic differentiation pathway are seen in Alzheimer's disease. Brain Behav Immu 2011, 25:539-547.

25. Elyaman W, Bradshaw EM, Uyttenhove C, Dardalhon V, Awasthi A, Imitola J, Bettelli E, Oukka M, van Snick J, Renauld JC, Kuchroo VK, Khoury SJ: IL-9 induces differentiation of TH17 cells and enhances function of FoxP3+ natural regulatory T cells. Proc Natl Acad Sci USA 2009, 106:12885-12890.

26. Eller K, Wolf D, Huber JM, Metz M, Mayer G, McKenzie AN, Maurer M, Rosenkranz AR, Wolf AM: IL-9 production by regulatory $T$ cells recruits mast cells that are essential for regulatory $T$ cell-induced immune suppression. J Immunol 2011, 186:83-91.

27. Van Snick J, Goethals A, Renauld JC, Van Roost E, Uyttenhove C, Rubira MR, Moritz RL, Simpson RJ: Cloning and characterization of a CDNA for a new mouse T cell growth factor (P40). J Exp Med 1989, 169:363-368.

28. Vink A, Warnier G, Brombacher F, Renauld JC: Interleukin 9-induced in vivo expansion of the B-1 lymphocyte population. J Exp Med 1999, 189:1413-1423.

29. Longphre M, Li D, Gallup M, Drori E, Ordoñez CL, Redman T, Wenzel S, Bice DE, Fahy JV, Basbaum C: Allergen-induced IL-9 directly stimulates mucin transcription in respiratory epithelial cells. J Clin Invest 1999, 104:1375-1382.

30. Faulkner H, Humphreys N, Renauld JC, Van Snick J, Grencis R: Interleukin-9 is involved in host protective immunity to intestinal nematode infection. Eur J Immunol 1997, 27:2536-2540.

31. Townsend JM, Fallon GP, Matthews JD, Smith P, Jolin EH, McKenzie NA: IL9-deficient mice establish fundamental roles for IL-9 in pulmonary mastocytosis and goblet cell hyperplasia but not T cell development. Immunity 2000, 13:573-583.

32. Pae S, Cho JY, Dayan S, Miller M, Pemberton AD, Broide DH: Chronic allergen challenge induces bronchial mast cell accumulation in BALB/C but not C57BL/6 mice and is independent of IL-9. Immunogenetics 2010 62:499-506.

33. McMillan SJ, Bishop B, Townsend MJ, McKenzie AN, Lloyd CM: The absence of interleukin 9 does not affect the development of allergen-induced pulmonary inflammation nor airway hyperreactivity. J Exp Med 2002, 195:51-57.

34. Harrington LE, Mangan PR, Weaver CT: Expanding the effector CD4 T-cell repertoire: the Th17 lineage. Curr Opin Immunol 2006, 18:349-356.

35. Nowak EC, Noelle RJ: Interleukin-9 as a T helper type 17 cytokine. Immunology 2010, 131:169-73.

36. Stephens LGeoffrey, Swerdlow Bonnie, Benjamin Ebony, Coyle JAnthony, Humbles Alison, Kolbeck Roland, Fung Michael: IL-9 is a Th17-derived cytokine that limits pathogenic activity in organ-specific autoimmune disease. European journal of immunology 2011, 41:952-962.

37. Angkasekwinai $P$, Chang SH, Thapa M, Watarai H, Dong C: Regulation of IL9 expression by IL-25 signaling. Nat Immunol 2010, 11:250-256.

doi:10.1186/1743-422X-8-267

Cite this article as: Qing et al:: Distinct different expression of Th17 and Th9 cells in coxsackie virus B3-induced mice viral myocarditis. Virology Journal $20118: 267$.

\section{Submit your next manuscript to BioMed Central and take full advantage of:}

- Convenient online submission

- Thorough peer review

- No space constraints or color figure charges

- Immediate publication on acceptance

- Inclusion in PubMed, CAS, Scopus and Google Scholar

- Research which is freely available for redistribution

Submit your manuscript at www.biomedcentral.com/submit
C) Biomed Central 